\title{
Non-Oil Sector and Economic Growth in Nigeria: The National Accounts Perspective
}

\author{
Abel Oghenevwoke IDEH ${ }^{1} \mathrm{PhD}$, Ndu Marvis OKOLO ${ }^{2}$, \\ Emeka Steve EMENGINI ${ }^{3} P h D$,
}

\begin{abstract}
This study examines the impact of expansion in non-oil sector on sustainable economic growth of Nigeria economy. The study sourced data from the Central bank of Nigeria (CBN) statistical bulletin covering the periods of 2000 - 2019. An economic growth model was formulated using the study variables and the model was estimated using vector auto-regression (VAR) techniques, other diagnostic tests such as Roots of Characteristic Polynomial for VAR model stability, Augmented Dickey-Fuller test for time series stationarity, and granger causality tests were conducted to ensure the reliability of the model estimates. The analysis revealed that the estimated model is stable while the VAR and variance decomposition results shows that real gross domestic product is strongly endogenous in the short run but weakly endogenous in the long run. Further findings suggest that in the long run non-oil sector is strongly endogenous to real gross domestic product ( $92 \%$ contribution). The study, therefore, recommends diversification of the Nigerian economy by focusing more attention on agriculture, solid minerals, and service sectors as they tend to influence economic growth in the long run. More so, improved frameworks of accounting in areas of non-oil revenues are desirable for the accountancy profession.
\end{abstract}

Keywords: Non-oil revenue; Diversification; Agriculture; Agrarian society; Economic growth; Accountancy profession JEL Classification: E6, H1, H2

\section{Introduction}

From the creation of the state called "Nigeria", it has always been an agrarian society through cash crops like palm produce, cocoa, groundnut, rubber, and timber. However, the discovering of oil and its boom in the 1970's made the country to swing into the production of oil that has resulted to a total neglect of the richly agro productiveness of the country. Anyaehie, and Areji (2015) noted that at the independence of Nigeria in 1960 , the main resource for the nation's was agriculture and extraction of solid minerals until oil discovery took over and the country forgot its starting points and lost direction. As enunciated in the study of Adams (2016); Okezie, and Azubike (2016) that Nigeria was a major producer of groundnuts (peanuts), cocoa, coffee, cotton, palm oil, and rubber, but lost it because of the over-dependence of oil.

The near-total dependence on the oil sector having considered its volatility and fluctuation in price level globally, has dire implications for the emerging economies. Even though oil revenue has been contributing immensely to the economic growth of the

${ }^{1}$ Ph.D. Department of Accounting and Finance, Faculty of the Social Sciences, Delta State University,

Abraka, PMB 1, Delta State, Nigeria.

${ }^{2}$ Department of Accounting and Finance, Faculty of the Social Sciences, Delta State University, Abraka,

${ }^{3}$ Department of Accountancy, University of Nigeria, Nsukka, Nigeria. 
country, it has not been reliable sources of revenue due to the unpredictable global crisis and fluctuation in the price level. For instance, Igberaese (2013), observed that in 19731974, there was Arab Oil Embargo; in 1980-1981, there was Iran-Iraq war; in 1981-1986, the oil production decreased and oil price collapsed; in 2001, there was Asian crisis while; in 2007-2011, there was global crisis which affected the prices of oil in the global market. Also, in June 2014 up till 2015, there was a dwindling of oil prices from \$112 per barrel and down-edged to $\$ 38$ per barrel; mainly aggravated by Middle East unrest and war. The global diminution in the oil supply and slow demand further down-edged the price to $\$ 31.4$ in 2016 and it has a negative implication on emerging countries (Mobosi, Okafor, \&Asoh, 2017). Hitherto, governments of Nigeria has not totally turn away from oil revenue, probably because she believes that the world will recover to normalcy in due time.

However, following the Corona-virus (COVID-19) pandemic outbreak in late 2019 and coupled with the shrink in price of crude oil as a result of the United State of America's reduction in the number of barrels the country imports from nations affected the global market terribly. As such, a country whose major revenue is dependent on oil has had no option than to re-consider diversification of its economy to the non-oil sector. This has in no small means contributed immensely to the shaking-economy of major oil exporters like Nigeria, Saudi Arabia, Iraq and Libya. The 2019-2020 year has been a turbulent one for Nigeria due to the double shock of oil price decline and the covid-19 pandemic that has prompted a call for total reliance of non-oil revenue to provide for the government and the public. The non-oil revenues are proceeds generated from sources other than the oilproducing activities. These revenues include those from companies not engaged in oil \& gas explorations. These other activity sectors comprise agriculture, industry, constructions, trade and service.

The reasons why diversification in the Nigerian economy is imperative is made more manifest from the consultative forum of the Minister of finance, Budget and Planning and the Organized Private Sector held on 10th July, 2020 concerning the impact of Global pandemic caused by COVID'19 on the implementation of the national budget. The forum highlighted the following issues, that crude oil prices declined sharply in the world market, with Bonny Light crude oil price dropping from a peak of US $\$ 72.2 \mathrm{pb}$ on January 7, 2020 to below US $\$ 20 \mathrm{pb}$ in April, 2020; In effect, the US $\$ 57$ crude oil price benchmark on which the 2020 budget was based became unsustainable. The impact of these developments is about 65\% decline in projected net 2020 government revenues from the oil and gas sector, with adverse consequences for foreign exchange inflows into the economy. There is a growth rate projection decline in Sub-Saharan Africa of about $-3.2 \%$ in 2020 and a steep recovery rate of 3.4\% in 2021 (Ministry of finance, Budget and Planning, 2020). Also, Nigeria has experienced decline in real GDP from $2.55 \%$ in the $4^{\text {th }}$ quarter of 2019 to $1.87 \%$ in the $1^{\text {st }}$ quarter of 2020 . This was based on effect of the Global pandemic of COVID'19. Generally, Real GDP was projected to contract by $4.2 \%$ in 2020 (NBS, 2020).

The Central Bank of Nigeria (2014) reported that agriculture became the second leading sector after oil since Nigeria GDP fell in 1970 from 48\% to 20.6\% in 1980 and subsequently grew in 2005 to $23.3 \%$. Again, the sectorial contribution to Nigerian economic growth stood at 39.21 in 2013 and $41.93 \%$ growth in GDP in the third quarter of 2014 (Orji 2018). There are diverse views and mixed literature as to which of either oil or non-oil revenue will sustain the economy and bring about the even development and 
economic growth that a country aspires for in meeting up the constitutional obligations of its government. As envisaged in Central Bank of Nigeria (1998), in Aigbedion, and Iyayi (2007), that the oil sector has contributed more to the total federally generated revenue than the non-oil revenue sectors and should not be neglected but rather diversify it because the sector has grown steadily over the years such that in 1970 and 1998, earning from oil rose from $75.3 \%$ to a peak of $84.1 \%$ respectively.

Other researchers are of the view that oil-based economy has not sufficiently sustained the nation since poverty level and unemployment rate is still on the increase and advocated for a sustainable means that is away from oil. Olayungbo, and Olayemi (2018) and Oyakhilomen and Zibah (2014) advised the government to channel her revenue-base to a more plural sector where agriculture plays the lead. This advice is purported to aid our agrarian society which ordinarily is in line with the encapsulated theory of comparative advantage. The notion of diversification is a means to channeling effort in producing that which the nation has more potentials. Hitherto, most studies supported a total overhaul of the economy rather than only the petroleum sector. The call has become a national debate. In view of the above, Onodugo, Amujiri, and Nwuba (2015), argued that diversification is very essential since crude oil is an exhaustible assets and its reliance can no longer sustain the Nigerian economy. Suberu, Ajala, Akande, Olure-Bank (2015) stated that options for diversifying an economy is numerous, and it ranges from agriculture, industrialization, tourism, financial services, entertainment, information and communication technology and mining.

As encapsulated in the works of Uzonwanne (2015), that diversification of the economy requires active participation in wide range of sectors, and strongly integrated into diverse regions that are able to generate vigorous growth and enormous potential in sustaining economic growth. Overtime, it has been observed that successive government had been shying away from a total neglect of the oil sector due to its volatility. Successive government had made efforts to implement policy that would lead to a well sustained economy. More so, from 2010-2011, a strategic reform known as Agricultural Transformation Agenda (ATA) was formulated, which stipulated that agriculture is a good venture and therefore every policy should be about supporting it. This ATA was seen as a good proposal to re-engage key stakeholders in Nigerian agriculture to diversify towards how an agrarian society could be self-sustained.

In 2016, the Central Bank of Nigeria under the leadership of President Mohammadu Buhari launched the Anchored Borrowers Programme (ABP) which was aimed at fasttracking access of rural famers to finance productivity. It facilitated a method where loans were given to farmers for improved agricultural produces; and encouraged mechanised farming to large production. More recently, the call for Nigeria to move away from oil and rely on locally made products called "Grow What You Eat" by the President Mohammadu Buhari led administration has been seen as a good move, most especially in this twofold shock of the country (fall in oil price and covid-19). Hence, this study seeks to ascertain the extent the non-oil revenue component (agriculture, solid mineral, trade, and service) can sustain the economy of Nigeria. As Orji, (2018) argued that if Nigerian economy is to be rescued to the path of sustainable growth and external viability, then, it must enthusiastically attend to the question of the place of non-oil export as regard to Nigeria 
economic growth and what dynamics are accountable for the advancement of the non-oil sector.

\section{Review Of Related Literature}

Nigeria has been known as an agrarian economy bestowed with substantial natural resources. These natural resources include; agricultural, solid mineral, mines and many others. Agriculture has narrowly been seen as the science of production of food and cash crops for exportation and consumption for mankind. Orji (2018) documented that mineral resources are categorised by the Geological Survey Department according to their uses as; Mineral fuels (lignite, coal, thorium, bitumen and uranium); Metallic minerals (manganese, lead, copper, iron, nickel, zinc, aluminum, and tin) and; Structural building minerals (limestone, stone, gypsum, asbestos, gravel, marble sand, anti-ceramic minerals - fluorspar, clay, dolomite, feldspar, asbestos).

Principally, these mineral resources are found in rural areas in most cases. Despite that, the rural area in Nigeria has not been developed very well to the extent of making reference to their God given gifts. No provision of good roads network, high unemployment rates, poor standard of living, and no access to good water and other essential public goods to the people of rural areas in the country is lacking. In the study of, Anríquez, and Stamoulis (2007), it was observed that in the global rating of 1.2 billion extremely poor people, $75 \%$ live in rural areas and for the most part they depend on agriculture, forestry, fisheries and related activities for survival. Omorogiuwa, Zivkovic, and Ademoh (2014) maintained that Nigeria has 75 percent of its land suitable for agriculture, but only about $40 \%$ is cultivated for this purpose thereby giving enough room for the country to focus on and as well attend to the food security, agricultural plans and employment for all. David, Noah, and Agbalajobi (2016) opined that though contribution of the mining sector to the GDP in the country is about $0.5 \%$ which is very poor and not favourable as matched to some SubSaharan countries such as DR Congo, Botswana, Namiba; the sector has the potentials to resuscitate the nation and brings the needed economic development if well employed.

Ariyo (1997) in Uzonwanne (2015) argued that agriculture in Nigeria has undergone many years of disrepair, unbalanced and defectively conceived government policies, mismanagement, dearth of meaningful inducement to farmers by government, basic infrastructure and numerous bureaucratic bottlenecks in executing policies. Sharing the view of Yesufu (1960), Olayungbo, et al., (2018) he saw reasons why government should consider horse-trading oil for non-oil revenue, because as it were, about $70 \%$ of the rural population of Nigeria engaged in one type of agricultural activity or the other and between 1963 and 1964, and the non-oil sector has greatly contributed up to 65\% of nation's gross domestic product (GDP). Doki, et al., (2019) see diversification as a turning point that would help in growing the GDP Per Capita of the country until such a time when the observed-turned point is no longer beneficial and it becomes necessary for the country to re-specialize. Diversification refers to a strategic direction that a nation used for the expansion of production or markets by means of either internal or external development (Adams, 2016). In the view of Anyaehie, et al., (2015), it does not always mean an increase in output but it encompasses stabilisation of economies by diversifying their economic base. 
Hence, diversification is seen as adaptive ability and it undergoes a long-term prospects. Some of the sectorial contributors to the pool of non-oil revenue in Nigeria has been projected to have performed well if not for the recklessness and abandonment of these sectors by the successive governments. Diversification is to be considered according to country-specific needs. It is a must for a country like Nigeria to embrace diversification in other to come out of the mess of price volatility of oil. In the Nigerian case, options for diversifying the economy abound. It ranges from; agriculture, solid minerals, trade and services. As justified in the study of, Akinlabi, and Tijani, (n.d) that agricultural sector is projected to contribute 34.4 percent variation in gross domestic product (GDP) between 1970 and 2010 in Nigeria but has suffered neglects during the hey-days of the oil boom in the 1970s. This agricultural sector comprises of crop production, livestock, forestry and fishing.

According to the National Bureau of Statistics (2019), trade comprises of saleable item that can generate revenues to the federal government while services includes art, entertainment and recreation, transportation, information communication technology, education, real estate and human health and social services. Arguably, the mining sector contribution to the economic growth seems saturated and envisaged diminishing returns. Economic growth on the other hand, refers to an increase in a country's national output over a period of time, usually one year. It is usually measured as the percentage increase in the Gross Domestic Product (GDP) of a country over a period of one year. Basically, the concept of economic growth is categorized into two measures which are the Nominal and Real. Doki and Tyokohol (2019) observed that the nominal absorbed inflation in its computation while the real GDP is the calculation where adjustment is made to eliminate the distorting effects of inflation. This study concentrated on the real gross domestic product due to the necessary provision for inflation. Ericsson, and Löf (2019), observed that the contribution of minerals and mining to GDP and exports has gotten to a maximum during mining boom in 2011 and regrettably the figures for mining's contribution had declined for most countries by 2016.

Mobosi, et al., (2017) argued that all the sectors that make up the non-oil sector such as; agriculture, industry, construction, services and trade should be adequately developed since they have shown serious contribution to output growth during the period of economic boom. The sector was the nation glory before the discovery of crude oil and having realized the pitfall the dependence on oil has caused the nation, the government has made enormous efforts to re-awaken the dead glory. NEITI (2013) has it in the audit report of 2007-2010, that over 2.21billion was remitted as royalty from companies operating in the oil sector, which about $\$ 51$.4billion was realised as taxes while annual surface rent payments amounted to over $\$ 173.94$ million alongside 122.92 million in levies to the Nigerian government. Most countries of the world now channel their strength in producing goods and rendering service that they were originally known for.

Succinctly documented in O’Toole (2007) that comparative cost advantage are now the reasoning behind some countries producing agricultural and mineral commodities while others produce industrial goods. In a situation where a country's share of agriculture in overall employment is huge, broad-based growth in agricultural incomes should be actually encouraged to prompt growth in the overall economy (Oyakhilomen, et al., 2014). The underpinning theory of this study is the comparative cost advantage theory. It was 
propounded by the Adams Smith in 1776, but was further pushed in by David Ricardo. The proponents of comparative cost advantages argued that a country should embark on the production of those goods or rendering of those services they can do best. Comparative cost advantage is believed to favour diversification of Nigerian economy simply because it centers on the fact that a country like Nigeria should produce more of her "best". In this case, Nigeria should comfortably rely on producing agro produce than the dependence on the exhaustible oil which she has no control over.

Igberaese (2013) observed that the mainstream economics argues that countries should produce and ex-port according to their comparative advantage and this will benefit countries if they accept the cost advantage of the trading country and focus on producing a commodity in which they can play a leading role. Edeme, Onoja, and Damulak (2018), believed that proper records and account of the solid minerals has not reflected in the nation's economy and as such there is need for wide awakening of inter-agency cooperation to monitor the size of mineral resources illicitly dripping the shores of the nation without proper account. The need to increase revenue from this sector has brought about many programmes initiated to revitalize the agricultural sector by the government (Ogunbiyi \& Abina, 2019). Some of these programmes in time past are; Anchored Borrowers Programme (ABP), National Economic Empowerment Development Strategy (NEEDS)and Agricultural Transformation Agenda (ATA). The most recent among the programme is diversification from oil dependence to non-oil based. This diversification should be holistic in nature and such; it should embrace accountability and transparency.

Suberu, et al. (2015) researched on the diversification of the Nigerian economy towards a sustainable growth and economic development. It employed the descriptive method of analysis. It is divulged that for the nation to break loose from the challenges intrinsic in a mono-economy, particularly one dominated by oil revenue, which is subject to price shocks and unfavourable quota arrangement, there is the need for diversification. It suggested agricultural sector is to be the probable choices for diversifying the economy. As a matter of fact, the unimpressive performance of non-oil revenue in time past has promoted oil revenue source as alternative source. However, the oil sector is characterized by external factors which ranges from price fluctuation and oil demands. The period between December 2019- July 2020 has left the world with unending ugly stories about the fall in oil price which COVID-19 has brought, hence, agrarian nations opt for diversification of their economy to the non-oil revenue.

Uzonwanne (2015) saw the need to research on economic diversification in Nigeria in the face of dwindling oil revenue. It made use of secondary data with the help of descriptive method. Its data revealed that Nigeria's over dependency on oil has contributed to the poor management of human capital/resources which has led to the migration of many talented citizens of the country to other countries in search of better life. It maintained further that the neglect of non-oil revenue has led to the constant depreciation in GDP of the country. Hence this clarion calls for urgent diversification of the Nigerian economy. More so, there exists a positive relationship between economic growth in Nigeria and diversification of other sectors since proper management of human resources, huge investment and concentration on agriculture has brought economic value. It therefore, recommends that Nigerian government should urgently create an enabling 
environment that will favour diversification of the economy that would discourage monoeconomy system and pay more attention to heterogeneous economy.

Oyakhilomen, et al.(2014) researched to find the relationship between agricultural production and the growth of Nigerian economy with the aim of poverty reduction. It employed the Time series data with the help of unit root tests and the bounds (ARDL) testing approach to co-integration. Its result revealed that agricultural production was significant in influencing the favourable trend of economic growth in Nigeria. It was recommended that adequate policies should be designed and implemented in alleviating rural poverty through puffed-up investments in agricultural development. Orji, (2018) studied the expansion of the Nigeria's economy via solid minerals and agriculture in the light of declining economy. The study employed correlation, co-integration, and regression tests. The result revealed that agricultural commodity export prices have significant and positive effect on Nigerian economic growth. It also revealed that solid mineral production has significant short and long-run impact on the Nigerian economy. The study recommended the implementation of a comprehensive inventory of mineral resource prospective as well as actively upholding the development of these resources for both local and foreign consumption.

Onodugo, et al. (2015) examined the diversification of the Nigerian economy as regards to economic development. It discovered that for Nigerian economy to be diversified there is need to have a dire paradigm shift in economic policies and political will in order to implement changes in policies. Its data also revealed that the neglect of agriculture has led to the constant depreciation in GDP of the country. Olayungbo, and Olayemi (2018) studied the dynamic relationships among non-oil revenue, government spending and economic growth in Nigeria. It's estimated the error correction model, impulse response and granger causality test; there was a mixed finding on the report. Firstly, it revealed a negative effect of government spending on economic growth while non-oil revenue showed positive effect on economic growth. Secondly, it found that non-oil revenue has negative shocks on economic growth while the government spending shock was positive.

David, et al., (2016) analysed the role of mining sector to Nigeria economic development. It made use of time series data with the help of Error Correction model in ascertaining the relationship between the mining sector's to the economic development. The finding discloses that the value of solid mineral has positive relationship on economic development in the country. It therefore recommended that Nigerian needs urgently develop her enormous mining potentials in such a manner that could lead to diversifying the economic and greatly achieve rapid economic growth. Olajide, Akinlabi, and Tijani, (n.d) examined the association of Agricultural resource on economic growth in Nigeria. Economic growth was proxy with gross domestic product (GDP). It employed the ordinary least square regression method (OLS). The results disclosed a positive relationship between gross domestic product (GDP) and agricultural output in Nigeria. It concludes that the government should make prosperous effort to improving the agricultural sector by granting the farmers incentives, access to good roads and providing adequate funding.

Okezie, and Azubike (2016) researched on the impact of Non-oil revenue to government revenue and economic growth in Nigeria. It considered secondary data obtained from the statistical bulletin of the Central bank of Nigeria which was analyzed 
using the Ordinary Least Squares Regression. Result of the analysis showed a positive and significant contribution of non-oil revenue to economic growth and positive but slightly insignificant contribution to government revenue. It proposed diversification for the government; any effort to sabotage this course must be nipped in the bud as the development of the non-oil sector remains a veritable channel for tapping into Nigeria's hidden wealth. Ogunbiyi, and Abina (2019) researched on the nexus between oil and nonoil revenue on economic growth. The economic development was proxy with human development index and stands for the dependent variable while oil and non-oil revenue were used as independent variable. It obtained data from the central bank of Nigeria bulletin and index mudi for the period 1981 to 2018. It employed the Descriptive Statistics, Augmented Dickey-Fuller Unit Root test, Johansen Co-integration and Error Correction Estimates. The estimated result discloses that oil revenue has a negative but significant relationship with human development index. It is believed that the negative contribution came as a result of the resource curse ideology.

On the other hand, non-oil revenue has a positive but insignificant association with dependent variable. Aptly, it considered the need for diversification of exportable product. Mobosi, et al., (2017) studied with the aim to finding why government diversification policy, Industrial Sector has impacted on the output of growth of Nigeria. It made use of time series data from the period 1970 - 2016. It adopted the Error Correction Classical Linear Regression approach and trend analyses. Hence, on the average, the results revealed that industrial share to GDP and output growth per capita in Nigeria exhibits positive reaction to the observable changes in the index of government diversification (DIV), human capital per person (HK), and number of persons employed (EMP) and domestic credit allocated to private sector by banks (CRA).

Edeme, et al., (2018) studied the role of solid mineral development in attaining sustainable growth in Nigeria. It adopted time-series with emphasis on GDP per capita, foreign trade balance, solid minerals output, domestic interest rate, gross domestic savings and inflation from 1960-2015. The Linear Growth Regression model showed that solid minerals positively and significantly affect sustainable growth. It further revealed that solid mineral is greatly significant but negatively associated with foreign exchange due largely to illegal movement of mineral commodities across the shores of the country. It recommended that much attention should be focused on the development of the solid minerals to help the economy from the vagaries of the present economic woes.

Doki, et al., (2019), carried out a study on how export diversification affects economic growth. It made use of the Bounds Co-integration test and the Error Correction Model (ECM) under the Autoregressive Distributed Lags (ARDL). The result showed that export diversification has positive but immaterial effect on economic growth in Nigeria in the long and short run. It thus, recommended that the government should intensify the effort to diversify the economy and properly channels towards the manufacturing and service industry export with the optimism that bulk of revenues comes from these sectors.

\section{Methods}

In achieving an in-depth analysis of the trend and the implication of diversification through non-oil revenue on Nigeria economic growth, the study considers four 
independent variables and a dependent variable. The independent variables of interest are non-oil revenues as proxied with the shares of; Agriculture to RGDP, Solid mineral to RGDP, Trade to RGDP and Service Industry to RGDP, while the dependent variable is the economic growth as proxied with Real Gross Domestic Product. It employed the annual time series data spanning from 2000-2019. These sets of data were sourced from the Statistical Bulletin of the Central Bankof Nigeria (CBN). It was analysed with the help of SPSS 20, and EViews 9.0.

Where: RGDP - Real Gross domestic product; AGRIC - Agriculture share of RGDP; SOLMNR - Solid Mineral share of RGDP; SRVCS - Service Industry share of RGDP; TRADE - Trade share of RGDP

A Multivariate Vector Auto-Regressive (VAR) model was used to gauge the effects of non-oil revenue on Nigeria's economic growth. VAR model is expressed as:

$$
y_{t}=A_{1} y_{t-1}+\cdots+A_{p} y_{t-p}+B x_{t}+\epsilon_{t} \ldots e q 1
$$

Where $y_{t}$ is a $k$ vector of endogenous variables, $x_{t}$ is a $d$ vector of exogenous variables, $A_{1}, \ldots, A_{p}$ and $B$ are matrices of coefficients to be estimated, and $\epsilon_{t}$ is a vector of innovations that may be contemporaneously correlated but are uncorrelated with their own lagged values and uncorrelated with all of the right-hand side variables. For a five different time series variables, denoted by $x_{t, 1}, x_{t, 2}, x_{t, 3}, x_{t, 4}$ and $x_{t, 5}$. The vector autoregressive model is as follows:

$$
\begin{aligned}
& x_{t, 1}=\alpha_{1}+\emptyset_{11} x_{t-1,1}+\emptyset_{12} x_{t-1,2}+\emptyset_{13} x_{t-1,3}+\emptyset_{14} x_{t-1,4}+\emptyset_{15} x_{t-1,5}+w_{t, 1} \ldots e q 2 \\
& x_{t, 2}=\alpha_{2}+\emptyset_{21} x_{t-1,1}+\emptyset_{22} x_{t-1,2}+\emptyset_{23} x_{t-1,3}+\emptyset_{24} x_{t-1,4}+\emptyset_{25} x_{t-1,5}+w_{t, 2} \ldots e q 3 \\
& x_{t, 3}=\alpha_{3}+\emptyset_{31} x_{t-1,1}+\emptyset_{32} x_{t-1,2}+\emptyset_{33} x_{t-1,3}+\emptyset_{34} x_{t-1,4}+\emptyset_{35} x_{t-1,5}+w_{t, 3} \ldots e q 4 \\
& x_{t, 4}=\alpha_{4}+\emptyset_{41} x_{t-1,1}+\emptyset_{42} x_{t-1,2}+\emptyset_{43} x_{t-1,3}+\emptyset_{44} x_{t-1,4}+\emptyset_{45} x_{t-1,5}+w_{t, 4} \ldots e q 5 \\
& x_{t, 5}=\alpha_{5}+\emptyset_{51} x_{t-1,1}+\emptyset_{52} x_{t-1,2}+\emptyset_{53} x_{t-1,3}+\emptyset_{54} x_{t-1,4}+\emptyset_{55} x_{t-1,5}+w_{t, 5} \ldots e q 6
\end{aligned}
$$

In order to capture the variables of the study, equations $2-6$ are represented in the explicit VAR forms as:

$$
\begin{aligned}
& \operatorname{rgdp}_{t, 1}=\alpha_{1}+\emptyset_{11} r g d p_{t-1,1}+\emptyset_{12} \text { agric }_{t-1,2}+\emptyset_{13} \text { solmnr }_{t-1,3}+\emptyset_{14} \operatorname{srvcs}_{t-1,4}+\emptyset_{15} \text { trade }_{t-1,5}+w_{t, 1} \ldots \text { eq7 } \\
& \text { agric }_{t, 2}=\alpha_{2}+\emptyset_{21} r g d p_{t-1,1}+\emptyset_{22} \text { agric }_{t-1,2}+\emptyset_{23} \text { solmnr }_{t-1,3}+\emptyset_{24} \operatorname{srvcs}_{t-1,4}+\emptyset_{25} \text { trade }_{t-1,5}+w_{t, 2} \ldots \text { eq8 } \\
& \text { solmnr }_{t, 3}=\alpha_{3}+\emptyset_{31} \text { rgdp }_{t-1,1}+\emptyset_{32} \text { agric }_{t-1,2}+\emptyset_{33} \text { solmnr }_{t-1,3}+\emptyset_{34} \operatorname{srvcs}_{t-1,4}+\emptyset_{35} \text { trade }_{t-1,5}+w_{t, 3} \ldots \text { eq } 9 \\
& \text { srvcs }_{t, 4}=\alpha_{4}+\emptyset_{41} r g d p_{t-1,1}+\emptyset_{42} \text { agric }_{t-1,2}+\emptyset_{43} \text { solmnr }_{t-1,3}+\emptyset_{44} \operatorname{srvcs~}_{t-1,4}+\emptyset_{45} \text { trade }_{t-1,5}+w_{t, 4} \ldots \text { eq10 } \\
& \text { trade }_{t, 5}=\alpha_{5}+\emptyset_{51} \text { rgdp }_{t-1,1}+\emptyset_{52} \text { agric }_{t-1,2}+\emptyset_{53} \text { solmnr }_{t-1,3}+\emptyset_{54} \operatorname{srvcs}_{t-1,4}+\emptyset_{55} \text { trade }_{t-1,5}+w_{t, 5} \ldots \text { eq11 }
\end{aligned}
$$

Since one of the basic assumptions of VAR is that the time series must be free from unit root, a major problem with time-series data is that they usually exhibit non-stationarity characteristics which perhaps may lead to spurious regression, this assumption is tested using Augmented Dickey-Fuller (ADF) as seen in equation 12 below.

$$
\Delta y_{t}=\beta_{0}-\beta_{1} t+\lambda Y t+\sum_{i=1}^{m} \alpha i \Delta Y t-i+\varepsilon_{t} \ldots e q 12
$$


$\Delta$ is the first difference operator, $a$ constant parameters and $\varepsilon_{t}$ is a stationary stochastic process. To determine the order of integration of series, equation 12 is modified to capture second difference on lagged first and $\mathrm{n}$ lags of second difference as follows:

$\left.\Delta y_{t}=\mu_{1} \Delta_{t-1}+\partial_{t} \Delta^{2} Y_{t-1}+\varepsilon_{i t} \quad(i=1), \ldots, n\right) \ldots e q 13$

$\mu$ and $\partial$ are constant parameters. The $n$ lagged difference terms are captured so that the error term $\varepsilon_{t}$ and $\varepsilon_{i t}$ in both equations are serially independent. A stationary time series is said to be integrated of order zero or 1(0), and a time series $Y_{t}$ is defined to be integrated of order one or 1(1) if $\Delta y_{t}$ is a stationary time series (Gujarati, 2003). Also, we conducted a Granger causality test to estimate the short-run link among the variables.

\section{Results and Discussions}

Table 4.1a: Summary Statistics

\begin{tabular}{|llllll|}
\hline & RGDP & AGRIC & SOLMNR & SRVCS & TRADE \\
\hline Mean & 7.678009 & 7.062374 & 4.686941 & 7.198177 & 6.837746 \\
Median & 7.717504 & 7.103274 & 4.690666 & 7.250124 & 6.930796 \\
Maximum & 7.853624 & 7.254272 & 5.010909 & 7.574574 & 7.068096 \\
Minimum & 7.374534 & 6.684932 & 4.323142 & 6.826669 & 6.427397 \\
Std. Dev. & 0.157857 & 0.167400 & 0.251323 & 0.216162 & 0.236631 \\
Skewness & -0.547820 & -0.936811 & -0.119805 & -0.225829 & -0.650901 \\
Kurtosis & 1.990928 & 3.074722 & 1.474077 & 1.870489 & 1.902801 \\
Jarque-Bera & 1.848876 & 2.930036 & 1.988212 & 1.233159 & 2.415446 \\
Probability & 0.396754 & 0.231074 & 0.370054 & 0.539788 & 0.298877 \\
Sum & 153.5602 & 141.2475 & 93.73882 & 143.9635 & 136.7549 \\
Sum Sq. Dev. & 0.473459 & 0.532430 & 1.200105 & 0.887791 & 1.063890 \\
Observations & 20 & 20 & 20 & 20 & 20 \\
\hline
\end{tabular}

Researchers' Computation via EViews 9.

Descriptive statistics test was carried out to determine if a data set had a normal distribution. It describes the averages of the mean, median, and standard deviation which are measures of spread and variation, skewness which looks at the symmetry and Kurtosis which looks at the centrality of the peak. From the result above, none of the non-oil revenue variables exhibited negative average values. The skewness values for all the variables were negative which implies that they are skewed to the left, however, SOLMNR \& SRVCS are approximately symmetric as its values -0.1198 and -0.2258 are greater than -0.5 while $R G D P(-0.5478)$ AGRIC (-0.9368) and TRADE (-0.6509) are all moderately skewed as its values were greater than -1 . Furthermore, the Jarque-Bera Statistics accepts the null hypothesis that all the variables are normally distributed. To ensure that there is no randomness in the data series, a Runs-test of randomness was carried out.

Table 4.1b: Runs test

\begin{tabular}{llllll}
\hline & RGDP & AGRIC & SOLMNR & SRVCS & TRADE \\
\hline Test Value $^{\mathrm{a}}$ & 52234181.6 & 12689609.1 & 49129.9 & 17824482.7 & 8539046.1 \\
Cases $<$ Test Value & 10 & 10 & 10 & 10 & 10 \\
Cases $>$ Test Value & 10 & 10 & 10 & 10 & 10 \\
Total Cases & 20 & 20 & 20 & 20 & 20 \\
Number of Runs & 2 & 2 & 2 & 2 & 2 \\
\hline
\end{tabular}




\begin{tabular}{llllll}
\hline $\mathrm{Z}$ & -3.905 & -3.905 & -3.905 & -3.905 & -3.905 \\
Asymp. Sig. (2-tailed) & .000 & .000 & .000 & .000 & .000 \\
\hline a. Median. Source: Researchers' Computation via SPSS 20.0
\end{tabular}

a. Median; Source: Researchers' Computation via SPSS 20.0

The runs-test of randomness suggests that we reject the null hypothesis that the sequence was produced in a random manner and accept the alternative of no randomness in the series as the $\mathrm{p}$-values of all variables were less than $1 \%$. Prior to assessing the conditional variance, it is practical to test for unit roots in the series using Augmented DickeyFuller(ADF).

Table 4.1c: Unit Root Test (ADF)

\begin{tabular}{llllllll}
\hline Variables & At level & \multicolumn{5}{c}{ At 1 $^{\text {st }}$ difference } & At 2 nd difference $^{\text {Decision }}$ \\
\hline & Stat. & Prob. & Stat. & Prob. & Stat. & Prob. & \\
RGDP & 0.433083 & 0.9977 & -2.796782 & 0.2167 & -4.474973 & 0.0153 & $\mathrm{I}(2)$ \\
AGRIC & -10.84697 & 0.0000 & - & - & - & - & $\mathrm{I}(0)$ \\
SOLMNR & -1.573455 & 0.7575 & -2.477866 & 0.3332 & -5.431380 & 0.0027 & $\mathrm{I}(2)$ \\
SRVCS & -2.718771 & 0.2411 & -2.396326 & 0.0367 & - & - & $\mathrm{I}(1)$ \\
TRADE & 0.451754 & 0.9980 & -3.914805 & 0.0335 & - & - & $\mathrm{I}(1)$ \\
\hline
\end{tabular}

Source: Researchers' Computation via EV Views 9.

The ADF unit root test indicates that RGDP and SOLMNR were stationary at order 2, SRVCS and TRADE were stationary at order 1 while AGRIC was stationary at level. A correlation test was carried out to understand the relatedness amongst the variables using Pearson Test of Correlation

Table 4.1d: Test of correlations

\begin{tabular}{|c|c|c|c|c|c|c|}
\hline & & RGDP & AGRIC & SOLMNR & SRVCS & TRADE \\
\hline \multirow[t]{4}{*}{ RGDP } & Pearson & 1 & & & & \\
\hline & Correlation & & & & & \\
\hline & Sig. (2-tailed) & & & & & \\
\hline & $\mathrm{N}$ & 20 & & & & \\
\hline \multirow[t]{4}{*}{ AGRIC } & Pearson & $.988^{* *}$ & 1 & & & \\
\hline & Correlation & & & & & \\
\hline & Sig. (2-tailed) & .000 & & & & \\
\hline & $\mathrm{N}$ & 20 & 20 & & & \\
\hline \multirow[t]{4}{*}{ SOLMNR } & Pearson & $.969^{* *}$ & $.937^{* *}$ & 1 & & \\
\hline & Correlation & & & & & \\
\hline & Sig. (2-tailed) & .000 & .000 & & & \\
\hline & $\mathrm{N}$ & 20 & 20 & 20 & & \\
\hline \multirow[t]{4}{*}{ SRVCS } & Pearson & $.951^{* *}$ & $.945^{* *}$ & $.930^{* *}$ & 1 & \\
\hline & Correlation & & & & & \\
\hline & Sig. (2-tailed) & .000 & .000 & .000 & & \\
\hline & $\mathrm{N}$ & 20 & 20 & 20 & 20 & \\
\hline \multirow[t]{4}{*}{ TRADE } & Pearson & $.994^{* *}$ & $.973^{* *}$ & $.959^{* *}$ & $.933^{* *}$ & 1 \\
\hline & Correlation & & & & & \\
\hline & Sig. (2-tailed) & .000 & .000 & .000 & .000 & \\
\hline & $\mathrm{N}$ & 20 & 20 & 20 & 20 & 20 \\
\hline
\end{tabular}

**. Correlation is significant at the 0.01 level (2-tailed). Researchers' Computation via SPSS 20.0 
The table above shows the correlation matrix between Real Gross Domestic Product and contributions of non-oil revenue variables to RGDP. The result shows that the correlation between RGDP and other non-oil revenue variables are positive and statistically significant. This is expected as each of the variables is part of the aggregate RDGP.

Table 4.2a: VAR Root

\begin{tabular}{ll}
\hline \multicolumn{2}{l}{ Roots of Characteristic Polynomial } \\
\hline Endogenous variables: RGDP AGRIC SOLMNR SRVCS TRADE \\
Exogenous variables: C \\
Lag specification: 12 \\
\\
Root & \\
& Modulus \\
5.717073 & 5.717073 \\
0.889417 & 0.889417 \\
$0.731408-0.446295 \mathrm{i}$ & 0.856818 \\
$0.731408+0.446295 \mathrm{i}$ & 0.856818 \\
$0.322715-0.640559 \mathrm{i}$ & 0.717259 \\
$0.322715+0.640559 \mathrm{i}$ & 0.717259 \\
$0.197925-0.562871 \mathrm{i}$ & 0.596656 \\
$0.197925+0.562871 \mathrm{i}$ & 0.596656 \\
$-0.373069-0.049885 \mathrm{i}$ & 0.376389 \\
$-0.373069+0.049885 \mathrm{i}$ & 0.376389 \\
\hline
\end{tabular}

Source: Researchers' Computation via EViews 9.

Fig 1. AR Root graph

Inverse Roots of AR Characteristic Polynomial

Researchers' Computation via EViews 9.

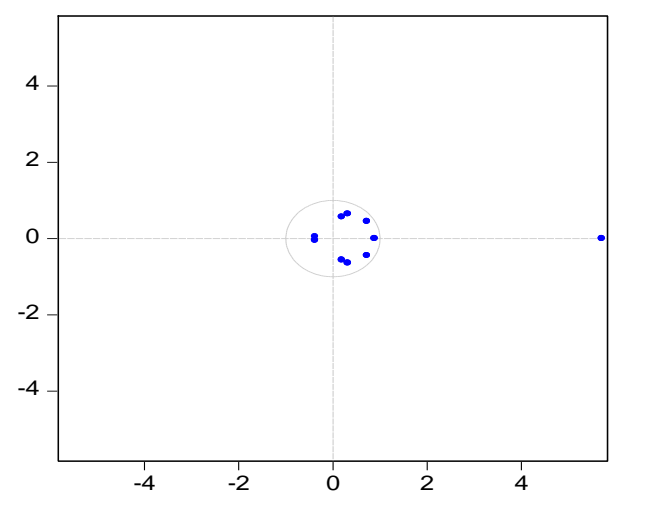

The stability of the AR roots of the polynomial was tested using AR root table and AR root graph diagnostic test. These two test reports the inverse roots of the characteristic AR polynomial; the estimated VAR is stable (stationary) if all roots have modulus less than one (for table) and lie inside the unit circle (for the graph). If the VAR is not stable, certain 
results (such as impulse response standard errors) are not valid. There will be $k p$ roots, where $k$ is the number of endogenous variables and $p$ is the largest lag. If you estimated a VEC with cointegrating relations, $k-r$ roots should be equal to unity. The result shows that all the VAR is stable as all the Modulus except one is less than one, and this result can be confirmed from the AR roots graph.

Table 4.2b: Vector Autoregression Estimates

\begin{tabular}{|c|c|c|c|c|c|}
\hline \multicolumn{6}{|c|}{ Sample (adjusted): 20022019} \\
\hline \multicolumn{6}{|c|}{ Included observations: 18 after adjustments } \\
\hline \multicolumn{6}{|c|}{ Standard errors in ( ) \& t-statistics in [ ] } \\
\hline & RGDP & AGRIC & SOLMNR & SRVCS & TRADE \\
\hline \multirow[t]{3}{*}{ RGDP(-1) } & 1.419213 & -0.381638 & 0.007161 & -3.605174 & 0.638995 \\
\hline & $(0.84158)$ & $(0.11559)$ & $(0.00555)$ & $(1.60722)$ & $(0.15191)$ \\
\hline & {$[1.68637]$} & {$[-3.30177]$} & {$[1.29061]$} & {$[-2.24311]$} & [4.20651] \\
\hline \multirow[t]{3}{*}{ RGDP(-2) } & -0.555097 & 0.091792 & -0.002479 & 2.371239 & -0.440973 \\
\hline & $(0.89797)$ & $(0.12333)$ & $(0.00592)$ & $(1.71492)$ & $(0.16209)$ \\
\hline & {$[-0.61817]$} & {$[0.74427]$} & {$[-0.41880]$} & {$[1.38271]$} & {$[-2.72061]$} \\
\hline \multirow[t]{3}{*}{ AGRIC(-1) } & -0.466203 & 0.509865 & -0.005123 & 1.627718 & -0.303120 \\
\hline & $(0.77934)$ & $(0.10704)$ & $(0.00514)$ & $(1.48836)$ & $(0.14067)$ \\
\hline & {$[-0.59820]$} & [ 4.76342] & {$[-0.99710]$} & [1.09363] & {$[-2.15480]$} \\
\hline \multirow[t]{3}{*}{ AGRIC(-2) } & 0.919950 & 0.306726 & -0.000326 & 1.443110 & 0.420801 \\
\hline & $(0.79939)$ & $(0.10979)$ & $(0.00527)$ & $(1.52664)$ & $(0.14429)$ \\
\hline & [ 1.15082$]$ & [2.79373] & {$[-0.06183]$} & [0.94528] & [2.91634] \\
\hline \multirow[t]{3}{*}{ SOLMNR(-1) } & -27.63767 & 37.40509 & 0.337738 & 215.5422 & -15.86699 \\
\hline & (99.7364) & $(13.6982)$ & $(0.65757)$ & $(190.473)$ & $(18.0026)$ \\
\hline & {$[-0.27711]$} & [2.73066] & {$[0.51362]$} & [1.13161] & {$[-0.88137]$} \\
\hline \multirow[t]{3}{*}{ SOLMNR(-2) } & 21.62410 & -20.96269 & 0.044524 & -474.1387 & 65.77796 \\
\hline & (116.345) & (15.9793) & $(0.76707)$ & (222.193) & (21.0006) \\
\hline & [ 0.18586$]$ & {$[-1.31186]$} & {$[0.05804]$} & [-2.13391] & [3.13220] \\
\hline \multirow[t]{3}{*}{ SRVCS(-1) } & 0.384610 & 0.199656 & -0.005569 & 8.253342 & -0.705716 \\
\hline & $(1.64684)$ & $(0.22618)$ & $(0.01086)$ & (3.14508) & $(0.29726)$ \\
\hline & {$[0.23354]$} & {$[0.88272]$} & {$[-0.51288]$} & [2.62421] & [-2.37409] \\
\hline \multirow[t]{3}{*}{ SRVCS(-2) } & -1.391471 & 0.070657 & -0.000485 & -2.494197 & -0.431242 \\
\hline & $(1.14904)$ & $(0.15781)$ & $(0.00758)$ & $(2.19440)$ & $(0.20740)$ \\
\hline & [-1.21099] & [0.44773] & {$[-0.06408]$} & {$[-1.13662]$} & {$[-2.07923]$} \\
\hline \multirow[t]{3}{*}{ TRADE(-1) } & -1.966340 & 0.615169 & -0.012876 & -4.663019 & 0.367254 \\
\hline & $(2.23844)$ & $(0.30744)$ & $(0.01476)$ & $(4.27490)$ & $(0.40404)$ \\
\hline & {$[-0.87844]$} & [2.00096] & {$[-0.87245]$} & [-1.09079] & [0.90895] \\
\hline \multirow[t]{3}{*}{ TRADE(-2) } & 3.935385 & 0.125445 & 0.014554 & -0.652089 & 1.437887 \\
\hline & $(2.21261)$ & $(0.30389)$ & $(0.01459)$ & $(4.22558)$ & $(0.39938)$ \\
\hline & [1.77861] & {$[0.41280]$} & [0.99768] & [-0.15432] & [3.60029] \\
\hline \multirow[t]{2}{*}{ C } & $\begin{array}{l}5744064 . \\
(7233425)\end{array}$ & 6838077 & $\begin{array}{r}-40899.41 \\
(47690.4)\end{array}$ & $\begin{array}{l}3323394 . \\
\end{array}$ & -1008961. \\
\hline & {$[0.79410]$} & [6.88304] & {$[-0.85760]$} & {$[0.24058]$} & {$[-0.77277]$} \\
\hline R-squared & 0.998165 & 0.999325 & 0.979609 & 0.976421 & 0.998709 \\
\hline Adj. R-squared & 0.995543 & 0.998360 & 0.950480 & 0.942736 & 0.996865 \\
\hline Sum sq. resids & $6.68 \mathrm{E}+12$ & $1.26 \mathrm{E}+11$ & $2.90 \mathrm{E}+08$ & $2.44 \mathrm{E}+13$ & $2.18 \mathrm{E}+11$ \\
\hline
\end{tabular}




\begin{tabular}{|c|c|c|c|c|c|}
\hline S.E. equation & 976607.5 & 134131.2 & 6438.837 & 1865094. & 176279.6 \\
\hline F-statistic & 380.7355 & 1035.706 & 33.62958 & 28.98708 & 541.5932 \\
\hline Log likelihood & -265.2939 & -229.5591 & -174.9026 & -276.9395 & -234.4776 \\
\hline Akaike AIC & 30.69932 & 26.72879 & 20.65584 & 31.99328 & 27.27529 \\
\hline Schwarz SC & 31.24343 & 27.27290 & 21.19996 & 32.53740 & 27.81941 \\
\hline Mean dependent & 53389322 & 13106933 & 60357.23 & 18814364 & 8343212. \\
\hline S.D. dependent & 14628714 & 3311848. & 28934.58 & 7793993. & 3148434. \\
\hline $\begin{array}{l}\text { Determinant resid } \\
\text { adj.) }\end{array}$ & covariance(dof & $2.07 \mathrm{E}+51$ & & & \\
\hline \multicolumn{2}{|c|}{ Determinant resid covariance } & $1.84 \mathrm{E}+49$ & & & \\
\hline \multicolumn{2}{|c|}{ Log likelihood } & -1148.625 & & & \\
\hline \multicolumn{2}{|c|}{ Akaike information criterion } & 133.7362 & & & \\
\hline \multicolumn{2}{|c|}{ Schwarz criterion } & 136.4567 & & & \\
\hline
\end{tabular}

Source: Researchers' Computation via EViews 9.

On the RGDP model, RGDP strongly influences its self, going by t-statistics of 1.686 (RGDP (-1)), the past realization of RGDP is associated with $141.9 \%$ increase in RGDP on average ceteris paribus. For the AGRIC coefficient, a percentage increase in AGRIC accounts for a $92 \%$ increase in RGDP, solid mineral (SOLMNR (-2)), and services (SRVCS $(-1))$ also have a significant influence on real gross domestic product. On the AGRIC model, the past realization of AGRIC strongly influences its self, going by the t-statistics of 4.76 in, solid mineral (SOLMNR (-1)) and trade (TRADE (-1)) also have a great influence on AGRIC. In the SOLMNR model, only past realization of solid mineral (SOLMNR (-1)) has a strong influence on its self, other variables exhibit a weak influence.

On SRVCS model, both real gross domestic product (RGDP (-2)), agriculture itself (AGRIC (-1)(-2)) solid mineral (SOLMNR (-1)) and services (SRVCS (-1)) strongly predicts revenue on government services. Likewise, on the trade model, all other non-oil revenue sources significantly predicted government revenue on trade. On the OLS estimate of the individual models, the $\mathrm{R}^{2}$ adjusted shows a good model fitting as its values were close to 1 with a very high F-statistics. A Variance Decomposition (VD) test was carried out to know how much of the future uncertainty of one time series is caused by the future shocks into the other time series in the model. This evolves, so the shocks on time series $\mathrm{X}_{1}$ may not be very important in the short-run but very important in the long run. In this study, the researchers selected 5 years as the forecast period; years one and two will be interpreted as the short-run period while 3 to 5 will be interpreted as the long-run period.

Table 4.2c: Variance Decomposition Result

\begin{tabular}{|c|c|c|c|c|c|c|}
\hline \multicolumn{7}{|c|}{ Variance Decomposition of RGDP: } \\
\hline Period & S.E. & RGDP & AGRIC & SOLMNR & SRVCS & TRADE \\
\hline 1 & 976607.5 & 100.0000 & 0.000000 & 0.000000 & 0.000000 & 0.000000 \\
\hline 2 & 1610675. & 74.61799 & 10.81129 & 7.683789 & 5.844548 & 1.042386 \\
\hline 3 & 7401451. & 7.566092 & 35.09164 & 26.27374 & 30.99752 & 0.071000 \\
\hline 4 & 57838547 & 8.697573 & 35.27888 & 25.07708 & 30.90592 & 0.040539 \\
\hline 5 & $4.67 \mathrm{E}+08$ & 9.004983 & 35.45265 & 24.73493 & 30.75779 & 0.049652 \\
\hline \multicolumn{7}{|c|}{ Variance Decomposition of AGRIC: } \\
\hline Period & S.E. & RGDP & AGRIC & SOLMNR & SRVCS & TRADE \\
\hline
\end{tabular}




\begin{tabular}{lllllll}
\hline $\mathbf{1}$ & 134131.2 & 0.122659 & 99.87734 & 0.000000 & 0.000000 & 0.000000 \\
$\mathbf{2}$ & 404609.8 & 13.46156 & 47.62008 & 5.711733 & 31.58988 & 1.616753 \\
$\mathbf{3}$ & 2014176. & 8.121947 & 38.82286 & 20.49807 & 32.49187 & 0.065243 \\
$\mathbf{4}$ & 15430549 & 8.738186 & 36.04155 & 24.16331 & 31.01251 & 0.044434 \\
$\mathbf{5}$ & $1.25 \mathrm{E}+08$ & 8.979942 & 35.53203 & 24.66418 & 30.77290 & 0.050946
\end{tabular}

Variance Decomposition of SOLMNR:

$\begin{array}{lllllll}\text { Period } & \text { S.E. } & \text { RGDP } & \text { AGRIC } & \text { SOLMNR } & \text { SRVCS } & \text { TRADE } \\ \mathbf{1} & 6438.837 & 63.07761 & 2.002783 & 34.91961 & 0.000000 & 0.000000 \\ \mathbf{2} & 15267.77 & 40.04008 & 10.31948 & 32.24234 & 16.90068 & 0.497417 \\ \mathbf{3} & 74993.90 & 11.75278 & 34.49177 & 23.52999 & 30.17972 & 0.045731 \\ \mathbf{4} & 585506.8 & 9.238097 & 35.80482 & 24.16997 & 30.73519 & 0.051929 \\ \mathbf{5} & 4768969 . & 9.039924 & 35.50448 & 24.66207 & 30.74127 & 0.052257\end{array}$

Variance Decomposition of SRVCS:

$\begin{array}{lllllll}\text { Period } & \text { S.E. } & \text { RGDP } & \text { AGRIC } & \text { SOLMNR } & \text { SRVCS } & \text { TRADE } \\ \mathbf{1} & 1865094 . & 0.558764 & 31.62425 & 33.57389 & 34.24310 & 0.000000 \\ \mathbf{2} & 15951481 & 6.474839 & 36.48788 & 25.12903 & 31.84849 & 0.059767 \\ \mathbf{3} & 1.31 \mathrm{E}+08 & 8.754195 & 35.66315 & 24.66863 & 30.86165 & 0.052378 \\ \mathbf{4} & 1.07 \mathrm{E}+09 & 8.996004 & 35.48242 & 24.71589 & 30.75384 & 0.051847 \\ \mathbf{5} & 8.72 \mathrm{E}+09 & 9.003363 & 35.47797 & 24.71675 & 30.74990 & 0.052025\end{array}$

Variance Decomposition of TRADE:

\begin{tabular}{llllcll} 
Period & S.E. & RGDP & AGRIC & SOLMNR & SRVCS & TRADE \\
$\mathbf{1}$ & 176279.6 & 34.05288 & 38.07346 & 4.598320 & 0.768052 & 22.50729 \\
$\mathbf{2}$ & 1500379. & 21.04090 & 31.51432 & 21.11522 & 25.97696 & 0.352593 \\
$\mathbf{3}$ & 12322793 & 9.684742 & 34.77680 & 25.03096 & 30.44175 & 0.065747 \\
$\mathbf{4}$ & $1.02 \mathrm{E}+08$ & 8.965310 & 35.47773 & 24.75327 & 30.74899 & 0.054692 \\
$\mathbf{5}$ & $8.31 \mathrm{E}+08$ & 8.991020 & 35.48733 & 24.71584 & 30.75329 & 0.052525 \\
\multicolumn{7}{l}{ Cholesky } \\
\hline
\end{tabular}

Source: Researchers' Computation via EV Views 9.

From the result of the RGDP model, in the short run, $100 \%$ of forecast error variance in the real gross domestic product is explained by the variable itself in year one. In year two, $74.6 \%$ of the forecast error variance is explained by the variable while approximately $25 \%$ was explained by other variables with AGRIC having the highest impact (10.8\%). That means other variables in the model do not have any strong influence on RGDP in the short run. The variables have a strong exogenous impact in the short run. In the long run, analysis shows that real gross domestic product does not have a strong influence on itself, its forecast error variance in year three is $7.5 \%$ while revenue from agriculture, revenue from services, and revenue from solid mineral were $35.2 \%, 30.9 \%$, and $26.3 \%$ respectively. Similar findings were also evident in years four and five. This implies that in the long run, real gross domestic product is strongly influenced by agriculture, services, and solid mineral revenues.

From the result of the AGRIC model, in the short run, $99.9 \%$ of forecast error variance in real revenue from agriculture is explained by the variable itself in year one. In year two, $47.6 \%$ of the forecast error variance is explained by the variable while approximately $52 \%$ was explained by other variables with SRVCS having the highest impact $(31.5 \%)$. That means other variables in the model do not have any strong influence on AGRIC in year one but in year two, they have a significant influence on the variable 
itself. In the long run, analysis shows that revenue from agriculture does not have a strong influence on itself, its forecast error variance in year three to five is below $40 \%$ while other variables control over $60 \%$ of the variation with revenue from services and solid mineral controlling the major share.

The result from SOLMNR shows that it does not influence itself in the short and long run. In the short run, less than $35 \%$ variability in its forecast error variance is caused by itself while in the long run, less than $25 \%$ variability in its forecast error variance is caused by itself. Real gross domestic product accounts for $63.1 \%$ and $40.0 \%$ of the variability in revenue from services in year one and two respectively while revenue from agriculture and services strongly influence solid mineral revenues throughout the long-run periods.

On SRVCS and TRADE models, the variables do not have a strong influence on themselves both in the short and long run. Revenue from services is basically influenced by revenue from agriculture and solid minerals while on the TRADE model, real gross domestic product, and agriculture strongly influence it in the short run; agriculture, services, and solid minerals influence it in the long-run.

Table 4.2d: VAR Granger Causality/Block Exogeneity Wald Tests

\begin{tabular}{|c|c|c|c|}
\hline \multicolumn{4}{|c|}{ Sample: 120} \\
\hline \multicolumn{4}{|c|}{ Included observations: 18} \\
\hline \multicolumn{4}{|c|}{ Dependent variable: RGDP } \\
\hline Excluded & Chi-sq & df & Prob. \\
\hline AGRIC & 2.758511 & 2 & 0.2518 \\
\hline SOLMNR & 0.954946 & 2 & 0.6203 \\
\hline SRVCS & 0.866392 & 2 & 0.6484 \\
\hline TRADE & 1.677210 & 2 & 0.4323 \\
\hline All & 13.99521 & 8 & 0.0819 \\
\hline
\end{tabular}

Source: Researchers' Computation via EViews 9.

The aim of conducting pairwise Granger causality tests is to check whether an endogenous variable can be treated as an exogenous or explanatory variable. From the result on the table above, none of the variables has a significant probability value, suggesting that none has the power to granger cause RGDP single handedly, but they all can jointly cause a change in RGDP at 10\% level of significance (P-value 0.0819). These findings is in line with the variance decomposition results of RGDP, where most of the variables jointly pose a strong influence on RGDP forecast error variance in the long-run period.

\section{Conclusion and Recommendations}

This study has explored the impact of Non - oil sector diverfiscation on economic growth of Nigeria. The study conclusion revolves around fact that RGDP is strongly endogenous in the short run but weakly endogenous in the long run. But specifically our results reveal that in the long run, that real gross domestic product does not have a strong influence on itself, its forecast error variance in year three is $7.5 \%$ while revenue from agriculture, revenue from services, and revenue from solid mineral were $35.2 \%, 30.9 \%$, and $26.3 \%$ respectively; similar findings were also evident in years four and five. This implies that in the long run, real gross domestic product is strongly influenced by agriculture, services, and solid mineral revenues. 
Further findings suggest that in the future, revenue from agriculture, solid minerals, and services would strongly influence economic growth as they were strongly endogenous to RGDP. The results of our study corroborate with the viewpoints of prior studies conducted by Orji, (2018); Edeme, et al. (2018); and Doki, et al., (2019). The study, therefore, recommends diversification of the Nigerian economy by focusing more attention on agriculture, solid minerals, and service sectors as they tend to influence economic growth in the long run. More so, improved frameworks of accounting in areas of non-oil revenues are desirable for the accountancy profession.

The monetary authorities such as $\mathrm{CBN}$ should intensify action to grant free interest loan in conjunction with commercial banks to small and medium business enterprise that are into agro and allied production. Available infrastructures such as constant power supply, good road network and security architecture should be provided by government to facilitate production, trade and services. In addition, incentives and tax-holidays should be granted to local and international investors who are interested in investing in non-oil sectors of the Nigerian Economy. Appropriate legislation should be enacted by regulatory authorities to stop illegal mining and perhaps deployment of sophisticated technology to boost our mining sector for employment generation and boost to government revenue at all levels.

\section{References}

Adams (2016). Diversification of Nigeria Economy through Agricultural Production. IOSR Journal of Economics and Finance, 7(2), 104-107.

Anríquez, G., \& Stamoulis, K. (2007). Rural Development and Poverty Reduction: Is Agriculture Still the Key? ESA Working Paper No. 07-02. FAO, Rome.

Anyaehie, C. M., \& Areji, C. A. (2015). Economic Diversification for Sustainable Development in Nigeria. Open Journal of Political Science, 5, 87-94.

David, O. O., Noah, O. A., \& Agbalajobi, S. A. (2016). An Empirical Analysis of the Contribution of Mining Sector to Economic Development in Nigeria. Khazar Journal of Humanities and Social Sciences, 19(1), 88- 106.

Doki, O. N., \& Tyokohol, Y. M. (2019). Export Diversification and Economic Growth in Nigeria. International Journal of Economics and Financial Management, 4(2), 16- 28.

Edeme, K. R., Onoja, C. T., \& Damulak, D. D. (2018). Attaining Sustainable Growth in Nigeria: Any Role for Solid Mineral Development? Academic Journal of Economic Studies, 4(1), 105-110.

Ericsson, M., \& Löf, O. (2019). Mining's contribution to National Economies Between 1996 and 2016. Mineral Economics, 32, 223-250.

Igberaes, T. (2013). The Effect of Oil Dependency on Nigeria's Economic Growth. A paper presented to the International Institute of Social Studies, United State of America, for the award of masters degree of Arts in Development Studies. 1-44.

Mobosi, A. I., Okafor, J. C., \& Asoh, O. (2017). Government Diversification Policy, Industrial Sector and Output Growth in Nigeria. International Journal of Advanced Studies in Economics and Public Sector Management, 5(3), 143-158.

National Bureau of Statistics (2019). Nigeria Gross Domestic Product Report.https://www.nigerianstat.gov.ng/pdfuploads/GDP_Report_Q3_2019.pdf-Retrieved: on the 23th July, 2020.

NEITI (2013). Solid Minerals Industry Audit Report 2007-2010. Retrieved from: www.neiti.org.ng/index.php?q.../neiti-2007-2010-solid-minerals-audit-reports

Ogunbiyi, S. S., \& Abina, P. A. (2019). The Nexus between Oil and Non-Oil Revenue on Economic Development in Nigeria. International Journal of Economics, Business and Management Studies, 6(2), 355-365. 
Okezie, S. O., \& Azubike, J. U. (2016). Evaluation of the Contribution of Non Oil Revenue to Government Revenue and Economic Growth: Evidence from Nigeria. Journal of Accounting and Financial Management, 2(5), 41-51.

Olajide, O. T., Akinlabi, B. H., \& Tijani, A. A. (n.d). Agriculture Resource and Economic Growth in Nigeria. European Scientific Journal, 8(22), 103- 115.

Olayungbo, O. D., \& Olayemi, F.O. (2018). Dynamic relationships among non-oil revenue, government spending and economic growth in an oil producing country: Evidence from Nigeria. Future Business Journal, 4, 246-260.

Omorogiuwa, O., Zivkovic, J., \& Ademoh, F. (2014). The Role of Agriculture in the Economic Development of Nigeria. European Scientific Journal, 10(4), 133-147.

Onodugo, I. C., Amujiri, A. B., \& Nwuba, B. N. (2015). Diversification of the economy: A panacea for Nigerian economic development. International Journal of Multidisciplinary Research and Development, 2(5), 477-483.

Orji, M. C. (2018). Diversification of Nigeria's Economy through Agriculture and Solid Minerals in the Face of Dwindling Economy. International Journal of Advance Research and Innovation, 6(3),147-151.

Oyakhilomen, O. \& Zibah, G.R. (2014). Agricultural Production and Economic Growth in Nigeria: Implication for Rural Poverty Alleviation. Quarterly Journal of International Agriculture, 53(3), 207223.

Salami, G. O. (2018).Empirical Analysis of the Impact of Non-oil Revenue on Economic Growth: Nigerian Experience. International Journal of Economics, Commerce and Management, 5(6), 263-276.

Suberu, O. J., Ajala, O. A., Akande, M. O. \& Olure-Bank, A. (2015). Diversification of the Nigerian Economy towards a Sustainable Growth and Economic Development. International Journal of Economics, Finance and Management Sciences, 3(2), 107-114.

Uzonwanne, C. M. (2015). Economic Diversification in Nigeria in the Face of Dwindling Oil Revenue. Journal of Economics and Sustainable Development, 6(4), 61-67. 